\title{
Correction to: Simulation, mathematical modeling, fabrication and experimental analysis of piezoelectric acoustic sensor for energy harvesting applications
}

\author{
Vasudha Hegde $^{1}$ (1) - Siva S. Yellampalli ${ }^{2}$ H. M. Ravikumar ${ }^{3}$ \\ Published online: 5 January 2020 \\ (C) Springer-Verlag GmbH Germany, part of Springer Nature 2020
}

\section{Correction to: Microsystem Technologies}

https://doi.org/10.1007/s00542-019-04702-x

The article 'Simulation, mathematical modeling, fabrication and experimental analysis of piezoelectric acoustic sensor for energy harvesting applications', written by Vasudha Hegde, Siva S. Yellampalli, H. M. Ravikumar, was originally published electronically on the publisher's internet portal (currently SpringerLink) on 03 December
2019 with open access. With the author(s)' decision to step back from Open Choice, the copyright of the article changed on 11 December 2019 to (C) Springer-Verlag GmbH Germany, part of Springer Nature 2020 and the article is forthwith distributed under the terms of copyright.

The original article has been corrected.

Publisher's Note Springer Nature remains neutral with regard to jurisdictional claims in published maps and institutional affiliations.

The original article can be found online at https:// doi.org/10.1007/s00542-019-04702-x.

Vasudha Hegde

vasudha.hegde@nmit.ac.in

Siva S. Yellampalli

siva.yellampalli@gmail.com

H. M. Ravikumar

hmrgama@gmail.com

1 Electrical and Electronics Engineering, Nitte Meenakshi Institute of Technology, Bangalore, Karnataka, India

2 School of Engineering and Applied Sciences, SRM University, Amaravati, Andhra Pradesh, India

3 Electrical Power and Control Engineering, School of Electrical Engineering and Computing, Adama University of Science and Technology, Adama, Ethiopia 